\title{
1. What's at stake in the South China Sea? Geographical and geopolitical considerations
}

\section{Clive Schofield}

\section{INTRODUCTION}

The South China Sea ranks among the most geographically and geopolitically complex ocean spaces in the world. It certainly appears to have been one of its most vigorously contested, featuring multiple, longstanding and competing territorial and maritime jurisdictional claims. The objective of this chapter is to provide the geographical and geopolitical background to the frequently conflicting national maritime claims made by the South China Sea littoral States. This exercise is designed to provide the necessary contextual backdrop to considerations of the application of maritime joint development mechanisms and/or other provisional arrangements of a practical nature in the South China Sea.

With this in mind, key characteristics of the coastal geography of the South China Sea are outlined, notably the implications of its semienclosed nature and the baselines that have been defined along its coasts. The insular features of the South China Sea, many of which are subject to conflicting sovereignty claims, are then examined with particular reference to their potential maritime claims and role in the delimitation of maritime boundaries. The chapter then outlines the maritime jurisdictional claims of the South China Sea coastal States, including existing maritime boundary agreements and maritime joint development zones, as well as unilateral and historical maritime claims.

Accordingly, a spatial picture of the maritime geography of the South China Sea including the locations and extents of claims to maritime jurisdiction is built up. The chapter then proceeds to highlight the main geopolitical factors that arguably serve as key drivers for the South China Sea disputes. These include longstanding yet still powerful sovereignty imperatives, significant and growing marine resource interests and energy 
security concerns, crucial navigational and maritime trade considerations and evolving military and strategic factors.

\section{GEOGRAPHICAL CONSIDERATIONS AND CLAIMS TO MARITIME SPACE}

\section{A. Geographical Context}

The South China Sea is a large ocean space located between the southern coast of China and Taiwan to the north, the mainland and peninsular coasts of Southeast Asia to the west and the archipelagic island groups of the Philippines, Borneo and Indonesia to the east and south. This semi-enclosed sea is bordered by the six claimants to the disputed South China Sea islands (Brunei Darussalam (Brunei), the People's Republic of China (China), Malaysia, the Philippines, Taiwan, and Viet Nam) and two non-claimants (Indonesia and Singapore). Additionally, Cambodia and Thailand are located along the South China Sea's Gulf of Thailand extension.

The limits of the South China Sea have been defined as extending southwards from the Strait of Taiwan to around the $3^{\circ}$ South parallel of latitude. ${ }^{1}$ It has, however, been suggested that the $1^{\circ}$ North parallel of latitude may be a more appropriate southern limit. ${ }^{2}$ If the latter definition is taken, the total surface area of the South China Sea (including the Gulf of Thailand) has been calculated at approximately three million square kilometres (equivalent to around 874,660 square nautical miles (nm)). ${ }^{3}$ The coastal geography of the South China Sea is both characterised and complicated by the presence of a profusion of predominantly small islands, islets, rocks and reefs. These coastal fronts are directly related to the maritime claims of the claimants.

1 According to the International Hydrographic Organization, the southernmost defining point of the South China Sea is Lucipara Point on the east coast of Sumatra. See: International Hydrographic Organization, Limits of Oceans and Seas, Special Publication No 23, 3rd edn (Monte Carlo: IHO, 1953), at 30.

2 Hasjim Djalal, 'South China Sea Island Disputes', in MH Nordquist and JN Moore (eds), Security Flashpoints: Oil, Islands, Sea Access and Military Confrontation (The Hague: Martinus Nijhoff Publishers, 1998), 109-33, at 109.

3 Ibid. Technically the correct abbreviation for a nautical mile is ' $M$ ', while ' $n$ ' denotes nanometres. However, ' $\mathrm{nm}$ ' is widely used by many authorities (for example the UN Office of Ocean Affairs and the Law of the Sea) and appears to cause less confusion than ' $M$ ', which is often assumed to be an abbreviation for metres. 


\section{B. Baseline Claims}

National claims to maritime jurisdiction are fundamentally dependent on, first, possession of land territory with a coast and, second, the geography of the coast concerned. Indeed, it has been observed: '. . . the land dominates the sea and it dominates it by the intermediary of the coastal front'. ${ }^{4}$ More precisely, a coastal State's maritime claims are measured from baselines defined along its coasts. In the absence of any other claim, 'normal' baselines will be used coincident with the low-water line along the coast. However, relevant international law as represented by the United Nations Convention on the Law of the Sea (UNCLOS) ${ }^{5}$ provides for several types of straight line baselines to be drawn as an alternative to normal baselines. It is worth noting at this point that UNCLOS provides the fundamental legal framework governing maritime jurisdictional claims, which has gained widespread acceptance by the majority of the States in the world, including the South China Sea States (see below). ${ }^{6}$

Several of the South China Sea claimants have taken the view that their coastlines are complex enough to justify the application of straight baselines along large parts of their coastal fronts. Article 7 of UNCLOS allows coastal States to depart from normal, low-water line, baselines along selected parts of their coastlines. The intention of Article 7 is, essentially, to deal with particularly complex coastal geography where the configuration of the coastline is such that using 'highly irregular'7 normal baselines

4 Prosper Weil, The Law of Maritime Delimitation - Reflections (Cambridge: Grotius, 1989), at 50.

5 United Nations, United Nations Convention on the Law of the Sea, Publication No E97.V10, (United Nations, New York, 1983). See 1833 UNTS 3, opened for signature 10 December 1982, Montego Bay, Jamaica (entered into force 16 November 1994) ('UNCLOS' or 'the Convention'), online: United Nations http://www.un.org/Depts/los/convention_agreements/convention_overview_conv ention.htm.

6 At the time of writing there were 164 parties to UNCLOS, comprising 163 States plus the European Community. See United Nations, Status of the United Nations Convention on the Law of the Sea, of the Agreement relating to the implementation of Part XI of the Convention and of the Agreement for the implementation of the Convention relating to the conservation and management of straddling fish stocks and highly migratory fish stocks, New York, updated on 29 November 2012, online: United Nations http://www.un.org/Depts/los/reference_files/status2010. pdf.

7 See International Hydrographic Organization (with the International Oceanographic Commission and the International Association of Geodesy), A Manual on Technical Aspects of the United Nations Convention on the Law 
would result in similarly irregular maritime limits, such as a complex mosaic of enclaves or pockets of non-territorial sea areas within a State's territorial sea. ${ }^{8}$ In accordance with Article 7 of UNCLOS straight baselines may be drawn 'where the coastline is deeply indented and cut into, or if there is a fringe of islands along the coast in its immediate vicinity'. Rather than apply straight baselines to selected parts of their coastlines, however, both China and Viet Nam have opted to front the vast majority of their mainland coastlines with systems of straight baselines.

This liberal interpretation of the admittedly rather loosely phrased terms of Article 7 of UNCLOS runs counter to the view of the International Court of Justice, as expressed in its decision in the Qatar/Bahrain Case, where it stated unequivocally that the method of straight baselines in accordance with UNCLOS 'must be applied restrictively'. ${ }^{9}$ It is highly questionable whether the coastlines in question are sufficiently deeply indented, cut into, or feature a suitable fringe of islands sufficiently close to the coast to justify their being fronted by a system of straight baselines. Further, the Western terminus of the system in the Gulf of Thailand is at 'Point O', out to sea and joining the Cambodian baseline system (see below). Accordingly, these extensive claimed systems of straight baselines have been viewed as excessive by other States and been subject to international protests, notably from the United States. ${ }^{10}$

Viet Nam made a claim to straight baselines in $1977,{ }^{11}$ with the claim being implemented in 1982. ${ }^{12}$ Viet Nam's claimed straight baselines start in the north and extend for a distance of approximately $850 \mathrm{~nm}$ to

of the Sea, 1982, Special Publication no 51, 4th edn, (Monaco: International Hydrographic Bureau, 2006), Chapter 4, at 6.

8 United Nations, Baselines: An Examination of the Relevant Provisions of the United Nations Convention on the Law of the Sea (New York: Office for Ocean Affairs and the Law of the Sea, United Nations, 1989).

9 Maritime Delimitation and Territorial Questions between Qatar and Bahrain, Merits, Judgment (2001) ICJ Reports 40 ('Qatar/Bahrain'), at para 212, online: International Court of Justice http://www.icj-cij.org/docket/files/87/7027. pdf.

10 See generally, J Ashley Roach and Robert Smith, United States Responses to Excessive Maritime Claims (The Hague: Martinus Nijhoff Publishers, 1996).

11 The straight baselines were claimed through Viet Nam's Statement on the Territorial Sea, the Contiguous Zone, the Exclusive Economic Zone and the Continental Shelf of 12 May 1977, online: United Nations http://www.un.org/ Depts/los/LEGISLATIONANDTREATIES/PDFFILES/VNM_1977_Statement. pdf.

12 Declaration on Baseline of Territorial Waters of 12 November 1982, online: United Nations http://www.un.org/Depts/los/LEGISLATIONANDTREATIES/ PDFFILES/VNM_1982_Statement.pdf. 
enclose the entire Vietnamese coast south of the Gulf of Tonkin. ${ }^{13}$ The islands used as basepoints for Viet Nam's claimed straight baselines are small, scattered and largely distant from the mainland coast, such that of the nine turning points defined five are more than $50 \mathrm{~nm}$ offshore. Viet Nam's straight baselines claims have, consequently, been subject to critical appraisal by the US Department of State ${ }^{14}$ and have been subject to US ${ }^{15}$ and Thai protests. ${ }^{16}$

China enacted enabling legislation on baselines in $1992^{17}$ and partially defined the baselines in 1996. ${ }^{18}$ The 1996 claim defines straight baselines along the majority of its mainland coast. A detailed analysis of this baseline system was undertaken by the US Department of State. The analysis was highly critical of China's baseline claim on the basis that China's coastline does not meet the criteria laid out in Article 7 of UNCLOS for the application of straight baselines. ${ }^{19}$ It is worth noting with respect to China's straight baselines claims that this designation is only partial. While China defined straight baselines around the Paracel Islands ${ }^{20}$

13 US Department of State, 'Straight Baselines: Viet Nam', Limits in the Seas, No 99, (Washington DC: Bureau of Intelligence and Research, 12 December 1983), at 5 .

14 Ibid. In particular the US analysis highlighted that the longest distance between basepoints is $161.8 \mathrm{~nm}$, (the average being $84.6 \mathrm{~nm}$ ), that island basepoints averaged $39.4 \mathrm{~nm}$ offshore with a maximum of $80.7 \mathrm{~nm}$ offshore and that the internal waters claimed total approximately $27,000 \mathrm{~nm}^{2}\left(93,000 \mathrm{~km}^{2}\right)$.

15 The US protest note stated that 'there is no basis in international law for the system of straight baselines provided in the declaration of November 12, 1982'; see Roach and Smith, supra note 10, at 102.

16 The Thai protest note, dated 9 December 1985, stated that between points 0 and A7, Viet Nam's claimed straight baselines were 'at variance with the well-established rules of international law', referring to both the 1958 and 1982 Conventions, and concluded that: 'the Government of Thailand reserves all its rights under international law in relation to the sea areas in question and the airspace above them'; see UN Law of the Sea Bulletin 7 (April 1986), at 111.

17 See Law on the Territorial Sea and Contiguous Zone, 25 February 1992, online: United Nations http://www.un.org/Depts/los/LEGISLATIONANDTREATIES/ PDFFILES/CHN_1992_Law.pdf.

18 See Declaration of the Government of the People's Republic of China on the baselines of the territorial sea, 15 May 1996, online United Nations: http://www.un.org/Depts/los/LEGISLATIONANDTREATIES/PDFFILES/CH N_1996_Declaration.pdf.

19 See US Department of State, 'Straight Baseline Claim: China,' Limits in the Seas, No 117 (Washington, DC: Office of Ocean Affairs, Bureau of Oceans and International Environmental and Scientific Affairs, US Department of State, 9 July 1996), online: US Department of State http://www.state.gov/documents/organiza tion/57692.pdf.

20 Chen Degong, 'China and the Law of the Sea', Occasional Paper, Canberra, 
(a feature of the Chinese claim that has also been the subject of criticism), ${ }^{21}$ no straight baselines were defined around the disputed Spratly Islands, though such baselines could be designated in the future.

For its part Taiwan has defined its own system of straight baselines. This system of straight baselines is extensive and applies not only to Taiwan's main islands but also to Pratas Island and the Macclesfield Bank. While at first glance Taiwan's baselines claim gives the appearance of archipelagic baselines, they are, in fact, straight baselines, taking into account Taiwan's claim to represent China as a whole. Taiwan's claimed straight baselines, defined all the way around Taiwan's main islands, are similarly excessive in character. ${ }^{22}$

Malaysia has not publicised the location of its claimed straight baselines. Their existence can be inferred from an examination of official maps, notably the 1979 map (often referred to as the 'Malaysian Map') issued by the Malaysian Directorate of National Mapping on 21 December 1979 in order to illustrate Malaysia's agreed maritime boundaries and the limits of Malaysia's unilateral territorial sea and continental shelf claims. ${ }^{23}$ Although no baselines are shown on these maps, the fact that in certain areas the outer limit of the Malaysian territorial sea claim is marked with straight lines leads to the conclusion that Malaysia has necessarily constructed a system of straight baselines. Malaysia subsequently enacted legislation in 2006 that provides for the declaration of the coordinates of the basepoints for defining its baselines, though such coordinates have yet to be defined, or at least published. ${ }^{24}$ Further, the joint submission of

Northeast Asia Program, Research School of Pacific and Asian Studies, Australian National University, December 1996, at 23.

21 US Department of State, supra note 19, at 8.

22 A comprehensive and critical analysis of this claim is provided by the US Department of State; see: US Department of State, 'Taiwan's Maritime Claims,' Limits in the Seas, No. 127 (Washington DC: Bureau of Intelligence and Research, 15 November 2005).

23 The Peta Menunjukkan Sempadan Perairan dan Pelantar Benua Malaysia or 'Map Showing the Territorial Waters and Continental Shelf Boundaries of Malaysia,' often referred to as the Peta Baru ('New Map'), published by the Malaysian Directorate of National Mapping in two sheets. The location of these baselines may then be determined by drawing lines parallel to the outer limit of the Malaysian territorial sea claim but $12 \mathrm{~nm}$ landward of the straight line limits of the Malaysian territorial sea claim. See Clive Schofield and May Tan-Mullins, 'Claims, Conflicts and Cooperation in the Gulf of Thailand', (2008) 22 Ocean YB 75, at 86-7; and Mark J Valencia, 'Validity of Malaysia's Baselines and Territorial Sea Claim in the Northern Malacca Strait', (2003) 27 Marine Policy 367, at 367-73.

24 Vivian L Forbes, 'The Territorial Sea Datum of Malaysia', (2007) 14:4 MIMA Bulletin 3, at 7-8. 
Malaysia and Viet Nam with respect to extended continental shelf rights revealed the location of some of Malaysia's straight baselines, specifically those fronting the coast of the Malaysian provinces of Sarawak and Sabah on the South China Sea, through illustrating them on maps included in the joint submission. ${ }^{25}$

The straight baseline claims of Cambodia and, to a somewhat lesser extent, Thailand in the Gulf of Thailand are also questionable. Cambodia's present straight baselines, claimed in $1982,{ }^{26}$ join up with those of Viet Nam at a 'floating' point and join up small and disparate islets. While Thailand's 1970-vintage straight baselines in the Gulf of Thailand were relatively conservative, ${ }^{27}$ its 1992 designation of an additional area (Area 4) of straight baselines was considerably less so, ${ }^{28}$ and has excited international protests. ${ }^{29}$

The South China Sea is also host to two archipelagic States: Indonesia and the Philippines. Both have defined archipelagic baselines which are compliant with Article 47 of UNCLOS. Indonesia claimed archipelagic baselines from 1960 and has revised and refined its claims on several occasions since, notably through legislation in 1996 and regulations in 2002

25 Joint Submission to the Commission on the Limits of the Continental Shelf pursuant to Article 76, paragraph 8 of the United Nations Convention on the Law of the Sea 1982 in respect of the southern part of the South China Sea, Executive Summary, 6 May 2009, online: United Nations http://www.un.org/Depts/los/ clcs_new/submissions_files/submission_mysvnm_33_2009.htm.

26 Cambodia's claim was made through a Council of State Decree dated 13 July 1982. In this legislation Cambodia's baselines were defined as being 'straight baselines, linking the points of the coast and the furthest points of Kampuchea's [Cambodia's] furthest islands', online: United Nations http://www.un.org/ Depts/los/LEGISLATIONANDTREATIES/PDFFILES/KHM_1982_Decree. pdf.

27 Areas 1 and 2 of Thailand's straight baselines claim lie in the Gulf of Thailand. The other area (Area 3) is located on Thailand's western coast on the Andaman Sea. The announcement of the Prime Minister's Office concerning straight baselines and internal waters of Thailand was published in the Official Gazette, Special Volume 87, Chapter 52, 12 June 1970, online: United Nations http://www.un.org/Depts/los/LEGISLATIONANDTREATIES/PDFFILES/TH A_1970_Announcement.pdf.

28 United Nations, UN Law of the Sea Bulletin 25 (June 1994), at 82-84, online: United Nations http://www.un.org/Depts/los/LEGISLATIONANDTREATIES/ PDFFILES/THA_1992_Announcement.pdf.

29 For example, the US Department of State analysis of this extension to Thailand's claimed straight baselines stated categorically that 'clearly this is an excessive maritime claim'. See US Department of State, Straight Baseline Claim: Thailand, Limits in the Seas, No 122 (Washington, DC: Bureau of Oceans and International Environmental and Scientific Affairs, 8 September 2000), at 9. 
and $2008 .{ }^{30}$ Indonesia subsequently deposited documents detailing the location of its archipelagic baselines, including the coordinates of and a map illustrating the 195 turning points involved, with the United Nations Secretary-General on 11 March 2009. ${ }^{31}$ These archipelagic baselines encompass the outermost rocks and reefs of the Natuna Islands group in the southwest of the South China Sea.

For a considerable period the Philippines claim to baselines was at variance with the terms of UNCLOS. The baselines claimed by the Philippines in 1961 and revised in 1968 not only included a baselines segment (141 nm long) in excess of the maximum length permitted under Article 47(2) of UNCLOS (125 nm), but were framed as straight baselines with internal rather than archipelagic waters claimed within them. In 2009, however, the Philippines revised its baselines and brought them into line with UNCLOS. ${ }^{32}$ The Philippines now claims archipelagic baselines around its main archipelago and applies the 'regime of islands' to outlying islands claimed, such as Scarborough Reef (or Shoal) and those Spratly Islands claimed by the Philippines as part of its Kalayaan Island Group (KIG) claim. The inclusion of the disputed South China Sea islands in the Philippines legislation and reconfirmation of the Philippines sovereignty claims to these features led to protests from China on the grounds that this represented a violation of Chinese sovereignty. ${ }^{33}$ Further, the maritime claims of the Philippines remain problematic on account of its historically-inspired claim to the Philippines Treaty Limits (see below).

\section{A 'Labyrinth of Detached Shoals': The Islands of the South China Sea}

As noted, a key feature of the maritime geography of the South China Sea is the presence of a myriad of predominantly small islands, islets, rocks, cays, shoals and drying reefs. The main island groups of the South China Sea are as follows:

30 See Clive Schofield and Andi Arsana, 'Closing the Loop: Indonesia's Revised Archipelagic Baselines System’, Commentary (2009) 1 Aus J Mar \& Ocean Aff 2, at 57-62.

31 For maritime zone notification and a complete list of the coordinates, see online: United Nations http://www.un.org/Depts/los/LEGISLATIONAND TREATIES/STATEFILES/IDN.htm.

32 Republic Act No 9522, 10 March 2009.

33 'China lodges stern protest over Philippine bill,' Xinhua News Agency (18 February 2009), online: http://www.chinadaily.com.cn/china/2009-02/18/ content_7489838.htm. 
1. The Paracel Islands, located to the northeast which comprise around 130 islands, predominantly divided between the Crescent and Amphritite groups which are occupied by China but also claimed by Viet Nam. ${ }^{34}$

2. The Pratas Islands, located to the northeast of the South China Sea and comprising three islands made up of coral atolls and reef flats which are occupied by Taiwan. ${ }^{35}$

3. Scarborough Reef, to the northeast, which has been described as 'stepto on all sides and consists of a narrow belt of coral', which is predominantly submerged at high tide but surmounted by a 'tallest rock' $3 \mathrm{~m}$ high. This feature is disputed between China and the Philippines. ${ }^{36} \mathrm{~A}$ feature often associated with Scarborough Reef, especially by China, is Macclesfield Bank. This is an entirely submerged feature described as a 'below-water atoll' with a least depth of water over it of $9.1 \mathrm{~m} .{ }^{37}$

4. The Natuna Islands, located in the southwest of the South China Sea, are an extensive group of islands under uncontested Indonesian sovereignty. ${ }^{38}$

5. The Spratly Islands (see below).

With respect to the Spratly Islands, one notable early description of this complex and numerous group of insular features dating from 1889 aptly refers to a 'labyrinth of detached shoals' ${ }^{39}$ It can further be observed that traditionally the islands of the South China Sea have generally been ignored. Predominantly consisting of very small, uninhabited islets of little apparent intrinsic worth, they have long been regarded as little more than hazards to navigation. For example, British Admiralty navigational charts routinely marked (and still mark) the area occupied by the Spratly Islands, appropriately enough, as 'Dangerous Ground' ${ }^{40}$ Arguably it is only since

34 See United Kingdom Hydrographic Office (UKHO), China Sea Pilot, Vol 1, 8th edn, Admiralty Sailing Directions (Taunton: UKHO, 2010), at 75-8.

35 Ibid, at 78.

36 See United Kingdom Hydrographic Office, China Sea Pilot, Vol 2, 9th edn, Admiralty Sailing Directions (Taunton: UKHO, 2010), at 74.

37 See UKHO, China Sea Pilot, Vol 1, supra note 34, at 68-9.

38 Comprising an extensive group of islands in the southwestern South China Sea. See UKHO, China Sea Pilot, Vol 2, supra note 36, at 78-86.

39 AG Findlay, Indian Archipelago and China Directory, 3rd edn (Richard Holmes Laurie: London, 1889), at vi, quoted in David Hancox and JR Victor Prescott, Secret Hydrographic Surveys in the Spratly Islands (The Maritime Institute of Malaysia, Kuala Lumpur: 1997), at 1.

40 Clive Schofield, 'Dangerous Ground - A Geopolitical Overview of the South China Sea' in S Bateman and R Emmers (eds), The South China 
the expansion of national maritime claims offshore and growing awareness of the valuable marine resources that may be contained within these maritime spaces that disputes have surfaced.

It is generally well known the sovereignty disputes over islands in the South China Sea relate to the Paracel Islands group in the northwest (disputed between China and Viet Nam), the Scarborough Reef (or Shoal) in the northeast (between China and the Philippines), and the Spratly Islands group (claimed in whole or in part by Brunei, China/Taiwan, Malaysia, the Philippines and Viet Nam). ${ }^{41}$ What is often less well understood is the geographical characteristics of these island groups. For example there exists great uncertainty, on the part of media commentators and also in academic literature, as to the answer to the deceptively simple-sounding question: 'how many Spratly Islands are there?' On the face of it this seems surprising, given the concerted focus on disputes involving these islands, and on the South China Sea area, over a considerable period of time.

A key source of uncertainty relates to the lack of clarity over what type of insular feature is under discussion. 'Islands' of the South China Sea range from relatively large features, with their own water sources and vegetation which have been developed, for example, to host military garrisons and runways, to much smaller islets, rocks, low-tide elevations and reefs as well as entirely sub-surface features on which structures may have been built. These features are scattered over a considerable area of oceanestimated to be of the order of $240,000 \mathrm{~km}^{2} .{ }^{42}$ An additional source of confusion in this context is the fact that many of the features in question boast multiple names in a variety of languages. ${ }^{43}$ This complexity of insular features, coupled with uncertainties as to what to count and even how to refer to features, has led different commentators to arrive at radically different figures with respect to, for example, the number of 'islands' that make up the Spratly Islands. At one end of the spectrum it has been suggested that there are as many as $400^{44}$ or even 500 islands in the Spratly Islands

Sea: Towards a Cooperative Management Regime (Routledge: London, 2009), at $7-25$.

41 The littoral States give one or both of these island groups names in their respective vernaculars: for the sake of consistency and clarity English language toponyms will be used.

42 See Daniel J Dzurek, The Spratly Islands: Who's On First? (International Boundaries Research Unit: Durham, 1996), at 1.

43 See Schofield, supra note 40, at 9-10.

44 See Craig Snyder, 'The South China Sea Dispute: Prospects for Preventative Diplomacy', USIP Special Report, No 18 (United States Institute of Peace: Washington DC, August 1996), online: USIP http://www.usip.org/publications/ south-china-sea-dispute-prospects-preventive-diplomacy. 
group. ${ }^{45}$ Other commentators suggest figures in the range of 150-180. For example, Dzurek has suggested that there are 'more than 170 features with English names in the Spratly Islands'. ${ }^{46}$

With respect to types of insular feature, UNCLOS provides for several options. In brief these include islands and rocks, low-tide elevations, reefs and artificial islands. The Regime of Islands is provided for in a single article of UNCLOS, this being Article 121 which covers both islands and a sub-category of islands termed 'rocks'. The provisions of Article 121 have excited considerable debate over the years. ${ }^{47}$ Article 121(1) of UNCLOS is relatively uncontroversial, defining an island as 'a naturally formed area of land, surrounded by water, which is above water at high tide', as is the subsequent paragraph of the Article which states that the maritime claims made from islands should be determined in the same manner as for 'other land territory'. However, UNCLOS Article 121(3) provides for a subcategory of islands, 'rocks', that are incapable of supporting human habitation or an economic life of their own. Such features 'shall have no exclusive economic zone or continental shelf' - an enormous disadvantage in terms of capacity to generate claims to maritime jurisdiction. Going to theoretical extremes, if an island had no maritime neighbours within $400 \mathrm{~nm}$, it could generate $125,664^{2} \mathrm{~nm}\left(431,014 \mathrm{~km}^{2}\right)$ of territorial sea, exclusive economic zone (EEZ) and continental shelf rights as compared to the capacity of a 'rock' to generate a territorial sea claim of $452^{2} \mathrm{~nm}\left(1,550 \mathrm{~km}^{2}\right) .{ }^{48}$

45 See for example, Glen Hearns and Peter Tyedmers, 'Poseidon's Trident: biological Diversity Preservation, Resource Conservation and Conflict Avoidance in the South China Sea', in Gerald H Blake et al (eds), The Peaceful Management of Transboundary Resources (Graham and Trotman: London, 1995), at 290.

46 See Dzurek, supra note 42, at 1.

47 See for example, Jonathan I Charney, 'Rocks that cannot Sustain Human Habitation', (1999) 93 AJIL 4, at 863-78; Alexander GO Elferink, 'Clarifying Article 121(3) of the Law of the Sea Convention: the Limits Set by the Nature of International Legal Processes', (1998) 6 Boundary \& Security Bulletin 2, at 58-68; Barbara Kwaitkowska and Alfred HA Soons, 'Entitlement to Maritime Areas of Rocks which cannot Sustain Human Habitation or Economic Life of their Own', (1990) Netherlands YB of Int'l L XXI, at 139-81; JR Victor Prescott and Clive $\mathrm{H}$ Schofield, The Maritime Political Boundaries of the World (Leiden/Boston: Martinus Nijhoff Publishers, 2005), at 61-75; Jon M Van Dyke and RA Brooks, 'Uninhabited Islands: Their Impact on the Ownership of the Oceans' Resources', (1983) Ocean Devel \& Int'1 L 12, at 265-84; and Jon M Van Dyke, J Morgan and J Gurish, 'The Exclusive Economic Zone of the Northwestern Hawaiian Islands: When Do Uninhabited Islands Generate an EEZ?', (1988) 25 San Diego L Rev 3, at 425-94.

48 For the purposes of these theoretical calculations it is assumed that the insular features in question have no land area. 
To date, however, no reliable way of distinguishing between these types of insular feature has emerged, despite the fact that to do so is critical for determining their capacity to generate claims to maritime jurisdiction. In short, despite exhaustive analysis, for instance of the drafting history of Article 121 of UNCLOS, together with detailed analysis of past State practice and the jurisprudence of international courts and tribunals, Article 121 remains a conundrum and open to considerably varied interpretations.

Many of the features making up the disputed South China Sea islands, especially low-lying reef-type features, can be categorised as low-tide elevations, defined in Article 13 of UNCLOS as a 'naturally-formed area of land which is surrounded by water at low-tide but submerged at high-tide'. Such features are considered to be distinct from islands as a result of their being in an inundated state at high tide. Consequently, low tide elevations are not capable of generating claims to maritime space in their own right. Instead, they may be used as territorial sea basepoints, but only if the lowtide elevation in question falls wholly or partially within the breadth of the territorial sea measured from the normal baseline of a State's mainland or island coasts. ${ }^{49} \mathrm{~A}$ low-tide elevation's value for maritime jurisdictional claims is, therefore, geographically restricted to coastal locations. Such features have been termed 'parasitic basepoints' as their zone-generative capacity is reliant on their proximity to a mainland or island baseline..$^{50}$

As far as features such as banks and shoals that are never above low water are concerned, such features have no capacity to generate claims to maritime jurisdiction under UNCLOS. It should also be noted that despite submerged reef platforms having been used to build artificial structures, UNCLOS Article 60(8) states unambiguously that: 'Artificial islands, installation and structures do not possess the status of islands. They have no territorial sea of their own, and their presence does not affect the delimitation of the territorial sea, the exclusive economic zone or the continental shelf'. ${ }^{51}$

Overall it would seem that the vast majority of features making up the disputed 'islands' of the South China Sea and the Spratly 'Islands' in particular are not islands capable of generating extended claims to maritime jurisdiction in accordance with the first two paragraphs of Article 121

49 UNCLOS, Article 13(1).

50 Clive R Symmons, 'Some Problems Relating to the Definition of "Insular Formations" in International Law: Islands and Low-Tide Elevations' (1995) 1 Maritime Briefing 5, at 7.

51 UNCLOS, Article 60(5) does, however, provide that safety zones of not more than 500 metres may be declared around such artificial islands or installations. 
of UNCLOS. Indeed, it has been suggested that only 48 features among the Spratly Islands group are known to rise above high-tide and thus be subject to the regime of islands. ${ }^{52}$ While some of these above high-tide features among the Spratlys are relatively substantial features - the largest, Itu Aba, being $1.4 \mathrm{~km}$ long and $370 \mathrm{~m}$ wide with an area of approximately 50 hectares - and may conceivably be considered as 'full' islands from which EEZ and continental shelf rights could be advanced, it would seem likely that many of the other features that make up the disputed islands of the South China Sea, even if above water at high-tide, could well be reasonably classified as mere 'rocks' within the meaning of Article 121(3). It is also worth observing that none of the disputed islands boasts an indigenous population or longstanding history of habitation, only what are essentially garrisons of government personnel, and this can be regarded as a pertinent factor when considering the question of whether a feature is capable of sustaining 'human habitation' in accordance with UNCLOS Article 121(3). Accordingly, the vast majority of the disputed features generally termed Spratly 'Islands' are no more than low-tide elevations, or even submerged features with limited or no capacity to generate claims to maritime jurisdiction.

If features among the Spratly Islands are categorised as mere 'rocks' consistent with the terms of Article 121(3) of UNCLOS, and thus deemed incapable of supporting human habitation or an economic life of their own, their capacity to generate claims to maritime jurisdiction would be severely restricted. The debate over whether features are 'full' islands versus mere 'rocks' is, however, arguably something of a distraction. The disputed features, even the largest among them, are clearly small and have short coastal fronts. The lengths of the coastal fronts involved, and in particular the existence of a significant disparity in the lengths of relevant coasts, has proved to be an influential factor in maritime boundary delimitations in the past. ${ }^{53}$ Further, a review of the treatment of islands in the delimitation of maritime boundaries suggests that such features would consequently have a significantly reduced influence on the course of any

52 Prescott and Hancox provide the figure of 48. However, some commentators offer lower figures, supra note 39. For example, Dzurek offers the number 36, supra note 42 , at 1 .

53 In the context of maritime boundaries delimited through International Court of Justice rulings, the Libya/Malta and Jan Mayen cases provide relevant examples. See generally Continental Shelf (Libyan Arab JarnahiriyalMalta) (1985) ICJ Rep 13 (Libya/Malta) and Maritime Delimitation in the Area between Greenland and Jan Mayen (Denmark v Norway) (1993) ICJ Rep 38 (Jan Mayen Case). 
maritime boundary defined between, for example, the disputed islands and the surrounding mainland or main island coasts. Such a conclusion has been reinforced by recent rulings on the part of the International Court of Justice (ICJ) and International Tribunal on the Law of the Sea (ITLOS) on the delimitation of maritime boundaries where islands have been a key consideration. In both the Black Sea Case before the ICJ of 2009 and Bay of Bengal Case before ITLOS which concluded in 2012, islands were discounted as basepoints even before a provisional delimitation line based on equidistance was constructed. ${ }^{54}$

This, in turn, suggests that the potential maritime claims to be made from the disputed islands of the South China Sea, often illustrated by reference to maps giving these features full-effect in the generation of strict equidistance lines, is misleading. For example, an equidistance line constructed around the Spratly Islands and according them full-effect encompasses an area of approximately $165,000 \mathrm{~nm}^{2} .55$ However, debates over island status and the capacity of insular features to generate claims to maritime space, let alone their potential role in the delimitation of maritime boundaries, tend to be obscured by the claims to sovereignty over the territory of the islands themselves. Such sovereignty claims also manifest themselves in a physical sense as illustrated by the fact that all of the claimants, with the exception of Brunei, have sought to back up their territorial and maritime claims by occupying features among the disputed South China Sea islands. The resolution of these island sovereignty disputes can be regarded as an essential precursor to the settlement of overlapping maritime claims and the delimitation of maritime boundaries. Nonetheless, as subsequent chapters in this volume demonstrate, even highly complex and contentious disputes can be side-stepped through the application of maritime joint development arrangements and, further, this can be achieved in a manner that does not undermine the parties' existing sovereignty and jurisdictional claims.

54 In the Black Sea Case between Romania and Ukraine the island in question was Ukraine's Serpents' Island and in the Bay of Bengal Case between Bangladesh and Myanmar it was St. Martin's Island belonging to Bangladesh. See Maritime Delimitation in the Black Sea (Romania v Ukraine) (2009) ICJ Rep 61 (Black Sea Case), online: ICJ http://www.icj-cij.org/docket/files/132/14987.pdf, at para149; and Dispute Concerning Delimitation of the Maritime Boundary between Bangladesh and Myanmar in the Bay of Bengal (2012) Judgment, ITLOS Case No 16 (Bangladesh/Myanmar), at para 233, online: ITLOS http://www.itlos.org/filead$\mathrm{min} /$ itlos/documents/cases/case_no_16/1-C16_Judgment_14_02_2012.pdf.

55 Prescott and Schofield, supra note 47, at 457. 


\section{Converging Claims to Maritime Jurisdiction}

As previously noted, UNCLOS provides the generally accepted international legal framework governing maritime jurisdiction. Among the States bordering the South China Sea, Brunei, China, Indonesia, Malaysia, the Philippines, Singapore and Viet Nam have all signed and ratified UNCLOS. Of the Gulf of Thailand States, Cambodia has signed the Convention but has yet to ratify it. For its part Thailand signed the Convention in 1982 but only finally acceded to it in May 2011.56 Additionally, non-UN member Taiwan is not a party to the Convention.

A key achievement of UNCLOS was agreement on spatial limits for national claims to maritime jurisdiction, which are largely defined as extending to a set distance from baselines along the coast. ${ }^{57}$ The South China Sea claimants have proved to be enthusiastic in advancing such maritime claims. To a large degree these claims are broadly consistent with the terms of UNCLOS; comprising claims to $12 \mathrm{~nm}$-breadth territorial seas, contiguous zones to $24 \mathrm{~nm}$, EEZs to $200 \mathrm{~nm}$ and continental shelf rights. These claims, however, frequently only represent a general claim to jurisdiction to a specified distance measured from claimed baselines, rather than specifying the coordinates of a particular claim. There are, however, exceptions to this rule, both in terms of specifying the limits of unilateral maritime claims and with respect to their consistency with the terms of UNCLOS (see below).

The semi-enclosed nature of the South China Sea means that it is surrounded by numerous bordering States and entities. This feature of the South China Sea means that the maritime entitlements of the claimants tend to converge and overlap with one another. If $200 \mathrm{~nm}$ claims from the mainland and main island coastlines are defined, a substantial high seas pocket exists in the central part of the South China Sea. This 'doughnut hole' is reduced in area but not eliminated once $200 \mathrm{~nm}$ limits are constructed from straight and archipelagic baselines as compared with claims from normal, low-water line baselines along the coast. However, this potential high seas pocket disappears entirely if extended claims to maritime jurisdiction (that is, to EEZ and continental shelf rights) are made from the disputed islands of the South China Sea. As noted many of the 'islands' of the South China Sea, for instance among the Spratly Islands,

56 See United Nations, supra note 6.

57 The notable exception to this general rule is provided by the definition of the outer limits of the continental shelf where it extends seawards of the $200 \mathrm{~nm}$ limit. Article 76 of UNCLOS provides a complex series of criteria in this respect which include geophysical factors as well as distance measurements. 
could be classified as either 'rocks' within the meaning of Article 121(3) of UNCLOS, or low-tide elevations, or even sub-surface features and as such are incapable of generating claims to EEZ and continental shelf rights (and, indeed, any maritime claims in the case of features permanently below the low-water level). Indeed, there are indications that some of the South China Sea littoral States regard all of the Spratly Islands as no more than 'rocks', meaning that a high seas doughnut hole would exist in the South China Sea (see below). Other claimants appear to take a different view. It can be observed that even if only a few of the larger features among the disputed islands are capable of generating extended maritime claims, this potential South China Sea high seas pocket would disappear, or at the least be radically curtailed in area. ${ }^{58}$

\section{E. Existing Agreements}

Despite its well-earned reputation as an arena for disputes and conflict, agreements on maritime boundary delimitation are not entirely absent from the South China Sea. Indeed, though progress has tended to have been incremental and partial in character, several boundary treaties have been concluded, including some in recent times. Examples include the Thailand and Malaysia territorial sea delimitation of $1979^{59}$ and partial continental shelf delimitation of the same date, ${ }^{60}$ the Thailand-Viet Nam EEZ agreement of 1997, ${ }^{61}$ China and Viet Nam's 2000 agreement

58 For example, if EEZs are defined from Woody Island in the Paracel Islands group, from Itu Aba, Spratly Island and Thitu Island in the Spratly Islands and also from Scarborough Shoal, the high seas pocket is almost entirely eliminated. It is worth noting, however, that these features are not of comparable size as Scarborough Shoal in particular is significantly smaller.

59 Treaty between the Kingdom of Thailand and [the Republic of] Malaysia Relating to the Delimitation of the Territorial Seas of the Two Countries of 24 October 1979. See Jonathan I Charney and Lewis M Alexander (eds), International Maritime Boundaries, Vols I \& II (Dordrecht: Martinus Nijhoff, 1993), at 1,096-1,098, online: United Nations http://www.un.org/Depts/los/ LEGISLATIONANDTREATIES/PDFFILES/TREATIES/THA-MYS1979TS. PDF.

60 Memorandum of Understanding between Malaysia and the Kingdom of Thailand on the Delimitation of the Continental Shelf Boundary between the Two Countries in the Gulf of Thailand was signed on 24 October 1979. See Charney and Alexander, supra note 59 at 1,105-1,107.

61 Agreement between the Government of the Kingdom of Thailand and the Government of the Socialist Republic of Viet Nam on the Delimitation of the Maritime Boundaries between the Two Countries in the Gulf of Thailand. See JI Charney and RW Smith (eds), International Maritime Boundaries, Vol IV 
on maritime boundary delimitation through the Gulf of Tonkin/Beibu Gulf, ${ }^{62}$ the Indonesia-Viet Nam continental shelf boundary of $2003^{63}$ and Indonesia and Singapore's territorial sea boundary agreements of 1973 and 2009. ${ }^{64}$ Brunei and Malaysia also appear to have clarified their maritime boundary issues through a 16 March 2009 Exchange of Letters. ${ }^{65}$

The South China Sea also features multiple provisional arrangements of a practical nature in lieu or in addition to maritime boundary agreements. Such joint development mechanisms have been established

(Dordrecht: Martinus Nijhoff, 2002), at 2,692-2,694, online: United Nations http://www.un.org/Depts/los/LEGISLATIONANDTREATIES/PDFFILES/ TREATIES/THA-VNM1997MB.PDF.

62 Agreement between the Socialist Republic of Viet Nam and the People's Republic of China on the Delimitation of the Territorial Sea, Exclusive Economic Zone and Continental Shelf between the Two Countries in the Tonkin Gulf, 25 December 2000 (entry into force 30 June 2004). See David A Colson and Robert W Smith (eds), 'People's Republic of China-Viet Nam', International Maritime Boundaries, Vol V (Leiden, Martinus Nijhoff, 2005), at 3,745-3,758. See also Nguyen Hong Thao, 'Maritime Delimitation and Fishery Cooperation in the Tonkin Gulf', (2005) 36 Ocean Development and International Law, at 25-44.

63 Agreement between the Government of the Socialist Republic of Viet Nam and the Government of the Republic of Indonesia concerning the delimitation of the continental shelf boundary, 26 June 2003 (entry into force 29 May 2007). See David A Colson and Robert W Smith (eds), International Maritime Boundaries, Vol VI (Leiden, Martinus Nijhoff, 2005), at 4,301-4,315.

64 Agreement Stipulating the Territorial Sea Boundary Lines between Indonesia and the Republic of Singapore in the Strait of Singapore, 25 March 1973 (entry into force 29 August 1974). See The Geographer, 'Territorial Sea Boundary: Indonesia-Singapore', Limits in the Seas, No 60, 11 November 1974. See, also, Ministry of Foreign Affairs, Indonesia, 'The Signing of The Treaty Between The Republic of Indonesia and The Republic of Singapore Relating to The Delimitation of The Territorial Seas in the Western Part of the Strait of Singapore', Press Release Jakarta, 10 March 2009, online: Indonesia Ministry of Foreign Affairs http://www.deplu.go.id/_layouts/mobile/PortalDetail-PressReleaseLike. aspx?1=en\&ItemId=c148acb8-88c6-4e24-9dd3-352ec9cd90c2.

65 The territorial sea boundaries between Brunei and Malaysia were defined in 1958 out to the 100 fathom isobath through two British Orders in Council. See Charney and Alexander, supra note 59, at 915-928. Brunei's submission of preliminary information to the United Nations Commission on the Limits of the Continental Shelf further states that maritime boundaries between Brunei and Malaysia have been delimited by virtue of the 1958 Orders in Council and 'an Exchange of Letters dated 16 March 2009' which served to delimit territorial sea, EEZ and continental shelf rights 'to a distance of 200 nautical miles'. See Brunei-Darussalam's Preliminary Submission concerning the Outer Limits of its Continental Shelf, 12 May 2009, online: United Nations http://www.un.org/Depts/ los/clcs_new/commission_preliminary.htm. 
between Malaysia and Thailand concerning seabed energy resources (agreed in principle in 1979, ${ }^{66}$ implemented from 1990), between Malaysia and Viet Nam, also related to seabed hydrocarbon exploration and development in 1992, ${ }^{67}$ and between China and Viet Nam in 2000 concerning joint fishing activities as part of their above-mentioned maritime boundary treaty ${ }^{68}$ Cambodia and Thailand also agreed in principle to pursue an accord on maritime joint development for part of their overlapping claims area in 2001, although little progress has subsequently been achieved. ${ }^{69}$ These joint arrangements will be considered in more detail elsewhere in this volume but reference to them is included here as part of the overall jurisdictional scenario in the South China Sea. It is notable, however, that both the maritime boundary agreements and joint arrangements that have been concluded have been exclusively on a bilateral basis and largely towards the periphery of the South China Sea.

\section{F. Historic Claims}

While it is the case that most, if not all, of the claims to sovereignty over disputed territory, that is, islands, in the South China Sea owe something to history, there also exist claims to maritime space that are, apparently at least, based on historical factors. In particular Cambodia and Viet Nam have, since 1982, claimed an oblong area of 'joint historic waters' projecting from their coasts (but within their claimed straight baselines, in the Gulf of Thailand) ${ }^{70}$ - a claim that has given rise to international

66 Memorandum of Understanding between the Kingdom of Thailand and [the Republic of] Malaysia on the Establishment of a Joint Authority for the Exploitation of the Resources of the Sea-Bed in a Defined Area of the Continental Shelf of the Two Countries in the Gulf of Thailand, done on 21 February 1979. See Charney and Alexander, supra note 59, at 1107-1123, online: United Nations http:// www.un.org/Depts/los/LEGISLATIONANDTREATIES/PDFFILES/TREA TIES/THA-MYS1979CS.PDF.

67 Memorandum of Understanding between Malaysia and the Socialist Republic of Viet Nam for the Exploration and Exploitation of Petroleum in a Defined Area of the Continental Shelf Involving the Two Countries was signed on 5 June 1992 and entered into force on 4 June 1993. See Charney and Alexander, supra note 59, at 2335-2344.

68 Agreement on Fishery Co-operation in the Tonkin Gulf between the Government of the People's Republic of China and the Government of the Socialist Republic of Viet Nam, 25 December 2000. See Nguyen Hong Thao, supra note 62, at 25-44.

69 Indeed in late 2009 it was reported that Thailand intended to unilaterally abrogate the 2001 Memorandum of Understanding.

70 Agreement on Historic Waters of Viet Nam and Kampuchea, 7 July 1982. 
protests. ${ }^{71}$ The Philippines has also long claimed rights within its 'Treaty Limits' - the 'box' formed by several nineteenth and early twentieth century era treaties. ${ }^{72}$ In particular, the Philippines claims territorial sea rights within the Treaty Limits box, and thus out to $285 \mathrm{~nm}$ at its furthest extent from the Philippines baselines. ${ }^{73}$ This claim, and the Treaty Limits assertion generally, appear to be manifestly at variance to the terms of UNCLOS.

The Philippines has also defined an irregular pentagonal box in the South China Sea, terming the islands within this box, the 'Kalayaan Island Group' (KIG). However, the KIG box does not appear to represent a claim to historic waters but instead provides an indication of a claim to sovereignty to all the territories (that is, islands) within this area. This interpretation, supported by the above-mentioned 2009 baselines revision, leaves the South China Sea islands claimed by the Philippines outside the Philippine's archipelagic baselines, instead dealing with them under the 'regime of islands', and in a manner consistent with UNCLOS.

China's (in)famous dashed line claim is of particular note here. This dashed line claim (if it can be termed as such) remains shrouded in uncertainty. An 11-dashed line first appeared on a map issued in 1947 by the Republic of China authorities but was subsequently adopted by the PRC in 1949, albeit with two dashes removed from the early 1950s. ${ }^{74}$ These dashed lines are sometimes joined up by commentators to form a so-called 'U-shaped line' although it should be stressed that official Chinese sources consistently show a discontinuous line. What is also consistent is a lack

See Jonathan I Charney and Lewis M Alexander (eds), International Maritime Boundaries, vol III (Dordrecht: Martinus Nijhoff, 1998), at 2,364-2,365.

71 Notably on the part of Thailand and the United States. See United Nations, Law of the Sea Bulletin 7 (April 1986), at 111; and United Nations, Law of the Sea Bulletin 10 (November 1987), at 23.

72 Specifically, the Treaty of Peace between the United States and Spain (Treaty of Paris) of 10 December 1898, the Treaty between Spain and the United States for the Cession of Outlying Islands for the Philippines of 7 November 1900 (Cessation Treaty), and the Convention between the United States and Great Britain Delimiting the Philippine Archipelago and the State of Borneo of 2 January 1930 (Treaty of Washington).

73 Prescott and Schofield, supra note 47, at 452.

74 See for example, Li Jinming and Li Dexia, 'The Dotted Line on the Chinese Map of the South China Sea: A Note', (2003) 34 Ocean Devel \& Int'1 L 287; Zou Keyuan, 'The Chinese Traditional Maritime Boundary Line in the South China Sea and Its Legal Consequences for the Resolution of the Dispute over the Spratly Islands', (1997) 14 Int'l J Mar \& Coast L 52; Kuan-Hsiung Wang, 'The ROC's Maritime Claims and Practices with Special Reference to the South China Sea', (2010) 41 Ocean Devel \& Int'l L, at 237-52. 
of clarity as to what this dashed line actually signifies. It remains unclear whether the dashed line is a claim to sovereignty over the territory (that is, the disputed islands) within it, whether it is indicative of a unilateral claim to a maritime boundary or whether it represents a claim to the maritime spaces within the dashes, either as historic waters or another type of maritime zone. The significance of China's inclusion of the nine-dashed line in its protest notes with respect to the extended continental shelf submissions of Viet Nam alone, and Malaysia and Viet Nam jointly, similarly remains unclear. Nevertheless, several Chinese enforcement actions in the South China Sea in recent times strongly suggest that the nine-dashed line remains the basis for Chinese claims. These have included fisheries incidents in Indonesian claimed waters in the southwestern South China Sea ${ }^{75}$ as well as incidents related to oil exploration activities on the part of both the Philippines and Viet Nam. ${ }^{76}$ Further, in mid-2012 the China National Offshore Oil Corporation (CNOOC) designated a series of oil exploration blocks in close proximity to the Viet Namese coastline, yet just within the nine-dashed line which was also illustrated on the map showing the CNOOC blocks. ${ }^{77}$ These activities appear to be only justifiable on the basis of a claim to the limits of the nine-dashed line.

\section{G. Unilateral Maritime Claims}

While, as noted above, many of the South China Sea claimants, in common with many coastal States worldwide, simply make ambit claims to broad maritime jurisdictional zones, several of the claimants have been more specific regarding the spatial limits of at least some of their maritime

75 Andi Arsana and Clive Schofield, 'Indonesia's "Invisible" Border with China', in Beijing's Power and China's Borders: Twenty Neighbors in Asia, edited by Bruce A Elleman, Stephen Kotkin and Clive H Schofield (New York, NY: ME Sharpe Publishers, 2012), at 67-70.

76 Regarding incidents between China and the Philippines see, for example, Jerome Aning and Norman Bordadora, 'China snubs PH protest: Aquino to send "Spratlys expert" to Beijing', Philippine Daily Inquirer, 3 May 2011. See also L Bautista and $\mathrm{CH}$ Schofield, 'Philippine-China border relations' in S. Kotkin et al, supra note 75 , at 244 .. Concerning incidents between China and Viet Nam see, for example, Daniel Ten Kate, 'South China Sea Oil Rush Risks Clashes as U.S. Emboldens Viet Nam on Claims', Bloomberg, 27 May 2011, online: http:// www.bloomberg.com/news/2011-05-26/s-china-sea-oil-rush-risks-clashes-as-u-semboldens-vietnam.html.

77 See China National Offshore Oil Corporation (CNOOC), 'Notification of Part of Open Blocks in Waters under Jurisdiction of the People's Republic of China Available for Foreign Cooperation in the Year of 2012', 23 June 2012 http:// en.cnooc.com.cn/data/html/news/2012-06-23/english/322127.html. 
claims. In the Gulf of Thailand, all of the littoral States defined unilateral continental shelf claims in the 1970s, which substantially overlap with one another. ${ }^{78}$ In the South China Sea 'proper', as previously mentioned, Malaysia issued a map in 1979 that shows the limits of Malaysia's unilateral territorial sea and continental shelf claims. ${ }^{79}$ In 1988 Brunei similarly defined a rectangular maritime claim extending into the South China Sea by publishing a series of maps. ${ }^{80}$ In 2010 Indonesia also employed cartographic means to clarify its 'forward position' in terms of its maritime claims. ${ }^{81}$

\section{H. Extended Continental Shelf Submissions}

In 2009, in common with many coastal States around the world, Viet Nam alone $^{82}$ and Malaysia and Viet Nam jointly ${ }^{83}$ made submissions to the UN Commission on the Limits of the Continental Shelf (CLCS). ${ }^{84}$ These submissions are significant because they relate to areas seaward of the $200 \mathrm{~nm}$ limit from these States' mainland coasts. The implication of these submissions is that, as far as Malaysia and Viet Nam are concerned, the disputed islands of the South China Sea are, at best, no more than 'rocks' within the meaning of UNCLOS Article 121(3). This is fundamental because, as noted above, if the disputed islands are in fact islands capable

78 For analysis of these claims see Clive Schofield and May Tan-Mullins, supra note 23 , at $75-116$

79 The Peta Baru ('New Map'), supra note 23.

80 Maps Showing Continental Shelf of Brunei Darussalam (1988); and Maps Showing Fishery Limits of Brunei Darussalam (1988). Also of note is the Map Showing Territorial Waters of Brunei Darussalam (1987). See also Renate Haller-Trost, 'The Brunei-Malaysia Dispute over Territorial and Maritime Claims in International Law', (1994) 1 Maritime Briefing 3, International Boundaries Research Unit, at 4-5.

81 Bakosurtanal, Map of the Republic of Indonesia (Cibinong, 2010).

82 Submission to the Commission on the Limits of the Continental Shelf pursuant to Article 76, paragraph 8 of the United Nations Convention on the Law of the Sea 1982, Partial Submission in Respect of Viet Nam's Extended Continental Shelf: North Area (VNM-N), Executive Summary, 7 May 2009, online: United Nations http://www.un.org/Depts/los/clcs_new/submissions_files/mysvnm33_09/ chn_2009re_mys_vnm_e.pdf .

83 Joint Submission to the Commission on the Limits of the Continental Shelf pursuant to Article 76, paragraph 8 of the United Nations Convention on the Law of the Sea 1982 in respect of the southern part of the South China Sea, Executive Summary, 6 May 2009, online: United Nations http://www.un.org/Depts/los/ clcs_new/submissions_files/submission_mysvnm_33_2009.htm.

${ }^{84}$ See online: United Nations Commission on the Limits of the Continental Shelf http://www.un.org/Depts/los/clcs_new/clcs_home.htm. 
of generating EEZ rights, then no area of extended continental shelf exists in the South China Sea. ${ }^{85}$

These submissions became a point of contention between the South China Sea claimants with both of the above-mentioned submissions prompting near-identical protest notes from China which stated in a diplomatic note directed to the Secretary General of the United Nations dated the day after Malaysia and Viet Nam's joint submission was made, that China has 'indisputable sovereignty over the islands in the South China Sea', and that, consequently, Malaysia and Viet Nam's joint submission 'seriously infringed China's sovereignty'. ${ }^{86}$ These protest notes in turn led to counter assertions on the part of Malaysia and Viet Nam stating that their submissions 'constitute legitimate undertakings' in the implementation of its obligations as Parties to UNCLOS. ${ }^{87}$ Subsequently, communications have also been directed to the United Nations Secretary General by Indonesia ${ }^{88}$ and the Philippines, ${ }^{89}$ both protesting China's nine-dashed line, with the latter note leading to a robust response on the part of China. ${ }^{90}$

85 Sam Bateman and Clive Schofield, 'Outer Shelf Claims in the South China Sea: New Dimension to Old Disputes' (Singapore: RSIS Commentary, 1 July 2009).

86 See Note from the Permanent Mission of the People's Republic of China addressed to the Secretary General of the United Nations, CML/17/2009, 7 May 2009, online: United Nations http://www.un.org/Depts/los/clcs_new/submissions_ files/submission_mysvnm_33_2009.htm; see also, an English language translation of China's reaction to Viet Nam's submission at http://www.un.org/depts/los/ clcs_new/submissions_files/vnm37_09/chn_2009re_vnm.pdf.

87 See Note from the Permanent Mission of Malaysia to the United Nations addressed to the Secretary General of the United Nations, HA 24/09, and, Note from the Permanent Mission of the Socialist Republic of Viet Nam to the United Nations addressed to the Secretary General of the United Nations, 86/HC-2009, online: United Nations http://www.un.org/Depts/los/clcs_new/submissions_files/ submission_mysvnm_33_2009.htm; and, http://www.un.org/depts/los/clcs_new/ submissions_files/vnm37_09/vnm_re_chn_2009re_vnm.pdf.

88 See Note from the Permanent Mission of Indonesian to the United Nations to the Secretary-General of the United Nations, 8 July 2010, No. 840/POL-703/ VII/10, online: United Nations http://www.un.org/Depts/los/clcs_new/submis sions_files/mysvnm33_09/idn_2010re_mys_vnm_e.pdf.

89 See Note from the Permanent Mission of the Republic of the Philippines to the United Nations to the Secretary-General of the United Nations, No. 000228, 5 April 2011, online: United Nations http://www.un.org/Depts/los/clcs_new/submis sions_files/mysvnm33_09/phl_re_chn_2011.pdf.

90 See Note from the Permanent Mission of the People's Republic of China to the Secretary-General of the United Nations, CML/8/2011, 14 April 2011, online: United Nations http://www.un.org/Depts/los/clcs_new/submissions_files/ mysvnm33_09/chn_2011_re_phl_e.pdf. 
It is worth noting here that the CLCS is a scientific and technical role rather than legal one in the sense of adjudicating between competing submissions. Indeed, the CLCS lacks the mandate to address areas subject to a sovereignty dispute or subject to overlapping maritime claims. Furthermore, the Commission's recommendations are also specifically without prejudice to the delimitation of maritime boundaries with Article 76(10) of UNCLOS providing that ' $[\mathrm{t}]$ he provisions of this article are without prejudice to the question of delimitation of the continental shelf between States with opposite or adjacent coasts'. ${ }^{91}$

The extended continental shelf submissions process, and the reactions to the submissions made, is, however, of note in that these documents arguably assist in the interpretation of existing maritime claims in the South China Sea. While attention was focussed on China's inclusion of its nine-dashed line map with its protest notes, the language used in the Chinese protests is potentially instructive. In particular, China's note verbale in response to the above-mentioned submissions of Malaysia and Viet Nam stated that China has 'sovereignty' over waters 'adjacent' to the disputed South China Sea islands and 'sovereign rights' over 'relevant waters as well as the seabed and subsoil thereof'. This language is, arguably, consistent with claims to territorial sea, EEZ and continental shelf rights made from the disputed islands, as opposed to a claim to historic waters or similar within the nine-dashed line, as has been speculated. ${ }^{92}$ Further, in its response to the protest made by the Philippines, China was explicit in stating that 'China's Nansha [Spratly] Islands is fully entitled to Territorial Sea, EEZ, and Continental Shelf'. ${ }^{93}$ Unfortunately it is not possible to be definitive on this point as China's claim remains less than explicit. Moreover, China's recent enforcement actions and activities such as the issuing of oil concession blocks in the South China Sea, as alluded to above, would seem to run counter to any suggestion that Chinese maritime claims in the South China Sea are increasingly in keeping with UNCLOS.

91 See also Annex II of UNCLOS and the Rules of Procedure of the Commission on the Limits of the Continental Shelf. The current version of the Rules is contained in Doc CLCS/40/Rev 1 of 17 April 2008, online: United Nations http://www.un.org/Depts/los/clcs_new/commission_documents.htm\#Rules $\% 20$ of $\% 20$ Procedure.

92 Robert Beckman, 'South China Sea: Worsening Dispute or Growing Clarity in Claims?' (Singapore, RSIS Commentary, 16 August 2010).

93 See Note from the Permanent Mission of the People's Republic of China to the Secretary-General of the United Nations, supra note 90. 


\section{GEOPOLITICAL CONSIDERATIONS}

\section{A. Sovereignty}

Sovereignty remains a critical element of the South China Sea disputes. Such disputes involve sovereignty over territory (that is, islands) and also sovereignty and sovereign rights over maritime spaces. Although traditional Westphalian conceptions of bounded territorial States have been subject to concerted criticism and challenge prompted, for instance, by deepening globalisation, the territorial State has by no means withered away. On the one hand, globalisation has clearly led to increasingly unfettered flows of capital, ideas, information and to a large extent labour, across and within the boundaries of States, thereby arguably eroding the importance of international boundaries and undermining the significance and authority of territorial States themselves. This, in turn has led to the emergence of a developing literature challenging traditional assumptions concerning the role and relevance of bordered State sovereignties. There are, however, powerful countervailing forces favouring inertia in the international legal order and which serve to underpin territorial States. Further, while globalisation may be changing or diluting the significance of sovereignty and boundaries in some areas, in others they have been reinforced. For example security and environmental concerns have been deployed as a rationale for the reassertion of the role of territorial States and their international boundaries as barriers and filters against hostile 'other' influences and threats.

For all the merits of the contemporary discourse and critique of territorial States, such entities remain as the key actors and fundamental building blocks of the international legal system. Indeed, it remains deeply unclear whether the international legal order, with the concept of the territorial State at its heart, is indeed under terminal threat, not least for want of a viable alternative system. Certainly sovereignty as a concept appears to be alive and well, indeed enthusiastically embraced, in East and Southeast Asia, including its associated maritime spaces. In this context it is important to note that the law of the sea gives States a primary role (unsurprisingly since UNCLOS was the creation of States). Crucially, claims to maritime jurisdiction may only be made by States. ${ }^{94}$

94 This conclusion is implicit from the terms and language of the Convention and in particular its emphasis on the role of States. For example, in the preamble to UNCLOS reference is made to the desirability of establishing 'a legal order for the seas and oceans' through the Convention 'with due regard to the sovereignty of all States'. Further, among the few definitions of terms pro- 
Territorial States are, as the name suggests, dependent, at least in part, on the possession of a 'defined territory'. ${ }^{95}$ The fundamental linkage between States and their constituent territories in international legal terms, coupled with the powerful influences of nationalism, patriotism and the demands of domestic and international politics, means that States tend to have great attachment to territory. Consequently, such entities tend to vigorously defend any apparent threat to their constituent territories as a threat to part of a State's territory, however small, can be construed, especially to a domestic audience politically, as an assault on the territorial integrity of a given State and thus a threat to its legitimacy. This holds true no matter how small or apparently intrinsically worthless (for instance tiny, remote and uninhabited islets) such fragments of territory may appear from a detached, external perspective.

Disputed sovereignty, especially over land territory (disputed islands) remains a root cause, or at least explanation, for the South China Sea islands disputes, especially when coupled with the influences of historical competition and animosity. Compromising on sovereignty is especially challenging for territorial States, seemingly regardless of the remote, uninhabited and apparently desolate nature of the territory (islands) in question. It can be observed that this is especially the case where the legitimacy of the governments of the States involved is closely tied to nationalism and patriotism which, in turn, provides a strong imperative for the protection of perceived infringements of national sovereignty.

It is noticeable, however, that many sovereignty disputes over such far-flung islands, including those of the South China Sea, have only manifested themselves in the post-World War II period, as extended claims to maritime jurisdiction became more prevalent. This has tended to add maritime jurisdictional and thus marine resource access issues as significantly complicating factors in sovereignty disputes. However, although sovereignty disputes are difficult to overcome, it is nonetheless possible to

vided in Article 1 of UNCLOS, 'States Parties' is defined as 'States which have consented to be bound by this Convention and for which this Convention is in force'. Moreover, regarding claims to maritime zones of jurisdiction, States are given an exclusive role. For example, Article 2 of UNCLOS dealing with the territorial sea provides that ' $[\mathrm{t}]$ he sovereignty of a coastal State extends . . . Similar language prevails in respect of the other types of maritime zones covered by UNCLOS.

95 Article 1 of the Montevideo Convention on the Rights and Duties of States, provides that States should possess a 'defined territory', a permanent population, a government and the capacity to enter into international relations with other States. See the Montevideo Convention on the Rights and Duties of States opened for signature 26 December 1933, 165 LNTS 19 (entered into force 26 December 1934). 
do so, for instance through the delimitation of international boundaries or through innovative joint arrangements of a provisional and practical nature that are, moreover, 'sovereignty neutral' and therefore do not imperil existing sovereignty claims.

\section{B. South China Sea Oil Dreams ... or Illusions?}

A long-standing assumption with respect to the broad areas of overlapping maritime claims in the South China Sea is that they are host to substantial reserves of seabed energy resources. Indeed, the words 'potentially oil rich' are often seen in close proximity to 'South China Sea' or 'Spratly Islands'. Many such estimates are speculative, poorly supported and are thus frequently highly misleading. Nonetheless, persistent perceptions that the South China Sea represents a major potential source of seabed energy resources and even a 'second Persian Gulf' 96 is often suggested as a key driver in the South China Sea disputes. Recent incidents involving oil and gas surveying and exploration activities tend to reinforce the view that access to valuable oil and gas resources underlying contested waters is an important contributing factor to the South China Sea disputes.

Certainly the potential presence of substantial and, critically, closeto-hand reserves of, particularly, oil, would be extremely attractive to the South China Sea claimants in the face of their generally increasing energy security concerns. States in Northeast Asia such as South Korea and Japan have long been highly energy import dependent - Japan for instance importing 90 per cent of its oil requirements by sea. China became a net oil importer in 1993 and is predicted to be importing 60 per cent or more of its energy needs by 2020. In Southeast Asia, domestic production is generally plateauing or declining. This means that currently or recently exporting States such as Indonesia, Malaysia and Viet Nam already are, or are highly likely to become, oil importers in the near future. This trend is compounded by predictions that oil demand in these States is likely to continue to rise. Indeed, International Energy Agency (IEA) figures suggest that growth in demand in Southeast Asia and China coupled with maturing production there will mean that net oil imports are likely to quadruple by 2030 . In consequence imports would meet 74 per cent of Southeast Asia's oil demands, compared with 25 per cent in

96 Daniel Ten Kate, 'South China Sea Oil Rush Risks Clashes as US Emboldens Viet Nam on Claim', Tuoi Tre News, 30 May 2011, online: Tuoi Tre News http:// www.tuoitrenews.vn/cmlink/tuoitrenews/politics/china-s-power-thirst-underpinssovereignty-breach-1.32681. 
$2008 .{ }^{97}$ This, in turn, tends to underscore the importance of sea lanes security (see below).

These present and increasing energy security considerations go a long way to explaining not only the expansive maritime claims of the claimants, but also the general intransigence of these claimants with regard to their maritime claims - to compromise on maritime claims may be perceived as running the risk of 'missing out' on a particular claimant's perceived rightful share of the potential (though potentially illusory) oil bonanza. Suggestions that the Spratlys are host to enormous reserves of oil and gas should be viewed with caution, however. While parts of the South China Sea are prospective and have long attracted interest from the oil industry as well as the governments of coastal States, in light of the longstanding disputes in these regions, the actual presence and size of the seabed energy resources present within these contested areas have proved impossible to verify. Many estimates as to the oil and gas resource potential of the South China Sea tend to be highly speculative in character, precisely because of the lack of ground-truthing to information derived from exploration activities.

South China Sea oil and gas resource estimates also tend to vary wildly. While this is partially attributable to their essentially speculative nature, a key reason for the broad disparities that exist between different estimates is a failure to distinguish between undiscovered oil and gas resources and recoverable reserves. The industry 'rule of thumb' for frontier provinces suggests that only 10 per cent of estimated in situ resources can be recovered (though this figure can vary and is in any case a function of oil price and extraction technologies).$^{98}$ For example, characteristically optimistic Chinese estimates for the oil and gas potential of the South China Sea tend to deal in resources rather than reserves. A further source of uncertainty relates to geographical definition. Some estimates quoted for the South China Sea in fact relate to Southeast Asia as a whole and thus includes resources located in undisputed waters or outside the South China Sea entirely.

Moreover, many reports are less than rigorous in identifying the type of resource under discussion and in particular whether conventional or unconventional oil and gas resources are subject to appraisal. Conventional crude oil is defined as oil that is less dense than water which

97 International Energy Agency (IEA) (2009) World Energy Outlook 2009 (Paris: OECD/IEA).

98 This figure may be of the order of $30 \%$ in more established provinces, however. 
generally flows from the ground under pressure, and remains liquid at surface temperature and pressure. ${ }^{99}$ Unconventional crude oil includes resources such as oil shale, tar sands and deepwater oil resources. With regard to the latter type of oil resources, significant technological advances are increasingly allowing exploration and development in deep (that is, according to some definitions, water depths in excess of 1000 feet) and ultra-deep (over 5000 feet) waters. ${ }^{100}$ Such waters include parts of the South China Sea and exploration efforts are underway there as illustrated by China's recent domestic construction of semi-submersible, deepwater drilling rig capable of drilling in up to 3000 meters of water and the deployment of this rig in the northern South China Sea. ${ }^{101}$

In this context it is also worth noting that it has been suggested that the South China Sea is predominantly a gas-prone province. This is good news in that recovery rates from gas fields tend to be significantly higher than for oil fields ( 75 per cent vs. 10 per cent). That said, gas is a substantially less attractive resource than is oil in large part because of high dependence on oil as a key liquid fuel energy carrier, coupled with the significant limitations that exist in relation to the use of gas as a substitute for petroleumderived fuels. In particular, although it is feasible to use gas in the transport sector, the global economy is to an extent 'locked in' to technologies that demand oil-derived fuels. ${ }^{102}$ Further, estimates for South China Sea gas reserves suffer from uncertainties of a similar magnitude as is the case for oil and for analogous reasons (principally because of lack of exploration opportunities as a consequence of overlapping maritime claims). A further important consideration is that many of the more optimistic assessments of the gas resource potential of the South China Sea fail to distinguish between conventional and unconventional gas resources. That is, many optimistic estimates include gas hydrates. While gas hydrates offer con-

99 Conventional crude oil also includes lease condensate (a mixture of heavy hydrocarbons associated with gas production, which condenses to form a liquid at surface conditions) and liquefied petroleum gas (LPG) a mixture of light hydrocarbons associated with crude oil production and refining that is gaseous at surface conditions).

100 The figures of $1000 \mathrm{ft}(305 \mathrm{~m})$ for deepwater and $5000 \mathrm{ft}(1,524 \mathrm{~m})$ for ultradeepwater are used by the United States government. See, for example, Richard McLaughlin, 'Hydrocarbon Development in the Ultra-Deepwater Boundary Region of the Gulf of Mexico: Time to Reexamine a Comprehensive U.S.-Mexico Cooperation Agreement', (2008) 39 Ocean Devel \& Int'1 L 1, at 1.

101 See for example, Daniel Ten Kate, supra note 96.

102 For example, as a result of long vehicle fleet turnover times. See Nick A Owen and Clive H Schofield, 'Disputed South China Sea Hydrocarbons in Perspective', (2012) 36 Marine Policy 809, at 811. 
siderable potential as a future energy resource, at present their commercial development is well beyond the horizon. This is essentially because they rank as the most technically challenging, and therefore expensive, of unconventional gas resources. As a consequence of their position at the base of the hierarchy of gas resources, gas hydrates are only likely to be developed after less technically challenging and expensive gas resources are exploited. Given the enormous combined volume of other unconventional gas resources, development of gas hydrates is presently beyond any foreseeable timescale. Consequently, the inclusion of gas hydrates in gas resource estimates for the South China Sea significantly and unrealistically inflates such estimates and renders them highly suspect from the point of view of near to medium term energy security considerations. ${ }^{103}$

The potential oil and gas resources of the South China Sea should also be placed in a regional and global context. The States of East and Southeast Asia face immediate and increasingly pressing energy security worries, especially as demand is anticipated to continue trending sharply upwards. However, even if the South China Sea disputes were to be resolved tomorrow (a tall order indeed), and exploration activities could begin in earnest, South China Sea energy resources, should they in fact exist, would provide no instant solution. This is because it is usual for approximately 10 years to elapse between the discovery of a field and 'first oil' being delivered. Production from such a field would then need to build up over time such that the South China Sea resources would be unlikely to peak for a decade and a half following resolution (or shelving) of the territorial and maritime disputes in question. In any case, it also appears unlikely that South China Sea reserves are likely to significantly address existing and predicted energy demands, even taking into account the more optimistic resource estimates mentioned above. This suggests that the oil and gas resources of the South China Sea do not represent some kind of silver bullet for regional energy security concerns.

\section{Critical Sea Lanes}

The South China Sea is host to a series of Sea Lines of Communication (SLOCs) of regional and global significance. These SLOCs connect constricting 'chokepoints' that provide entry to and egress from the South China Sea. Of particular note in the southern part of the South China Sea are the Straits of Malacca and Singapore at the southwestern entrance to the South China Sea and the Karimata Strait providing access to the Java

103 Ibid, at 813. 
Sea and Indonesia's archipelagic waters and thus the Straits of Sunda. In the northern South China Sea the Taiwan Strait between Taiwan and mainland China and the Bashi and Balintang Channels located between Taiwan and the Philippines main island of Luzon are significant. The South China Sea can also be accessed to the east via the Mindoro Strait and Cape Verde Passage (connecting to the Sulu Sea within the archipelagic waters of the Philippines). Moreover the South China Sea can be entered via the Straits of Lombok and Makassar and then the Balabac Strait between the Philippines archipelago and Borneo. ${ }^{104}$ This route is particularly important because it is a favoured route for very large crude carriers (VLCCs) when fully laden and is also significant for LNG exports from Australia to China.

The SLOCs connecting these key chokepoints do not represent a single sea lane but rather a network of routes used for navigation. The precise route used by a particular ship is commonly influenced by its point of departure and intended destination, allied to weather considerations influenced by the time of year the voyage take place. ${ }^{105}$ What is worth noting, however, is that despite the fact that the disputed islands of the South China Sea are often referred to as being located on or straddling these SLOCs, in fact the island groups in question have long been regarded primarily as hazards to navigation - as shown by terminology such as 'Dangerous Ground' as mentioned above. Consequently, much maritime traffic, for instance travelling between the Malacca and Singapore Straits and ports in East and Northeast Asia, tends to sail well to the west of the disputed Spratly Islands. Similarly, the Palawan Passage route skirts the east of the Spratlys archipelago. ${ }^{106}$

Secure SLOCs and freedom of navigation are essential to the smooth functioning of the global economy as maritime transport continues to provide the 'backbone' of international trade with in excess of 80 per cent of global trade by volume being transported by sea. ${ }^{107}$ If anything this

104 See for example, Chris Rahman and Martin Tsamenyi, 'A Strategic Perspective on Security and Naval Issues in the South China Sea', 41 Ocean Devel \& Int'l L 315, at 316-17.

105 Ibid, at 317.

106 Chris Rahman and Martin Tsamenyi, supra note 104, at 316-18.

107 United Nations Conference on Trade and Development, Review of Maritime Transport 2008 (Geneva, 2008), at 8. Other estimates provide an even greater figure. For example the Rio Ocean Declaration of 2012 states that 'The international shipping sector transports $90 \%$ of global trade, making it a cornerstone of sustainable development.' See Rio Ocean Declaration, online: UNESCO http://www.unesco.org/new/fileadmin/MULTIMEDIA/HQ/SC/pdf/pdf_Rio_ Ocean_Declaration_2012.pdf. 
dependence on seaborne trade is accentuated for the generally resourcepoor but export-oriented States of East and Southeast Asia and in this context the SLOCs that traverse the South China Sea are unquestionably crucial. As noted above, there is also a strong, and increasing, energy security dimension to sea lane security in the region. As already mentioned, oil and gas import dependence appears set to rise sharply in the future and the vast majority of these resources will be carried by sea. The IEA's prediction, mentioned above, of quadrupling net oil imports by 2030 implies substantially increased tanker traffic in the future, thus emphasizing the significance of the SLOCs. A further consideration is that these waterways are not solely used for commercial traffic. The South China Sea and its SLOCs represents the shortest route between the Pacific and Indian Oceans and is therefore used as a transit route by, for example, naval vessels attached to the United States Pacific Command. SLOC security therefore remains a crucial and shared concern for all regional and indeed extra-regional States and is only likely to become more vital in the future.

\section{The Real Prize? Sustainable Marine Living Resources and the Environment}

The semi-enclosed, tropical environment of the South China Sea and Gulf of Thailand hosts marine environments of extraordinary richness in biodiversity terms. These environments support fisheries of significance in global, and certainly regional, terms. Indeed, it has been suggested that the South China Sea alone accounts for as much as one tenth of global fish catches. ${ }^{108}$ Other sources have suggested that South China Sea fisheries provide catches of the order of five million tonnes per annum. ${ }^{109}$ These marine living resources are fundamental to the food security of coastal populations numbered in the hundreds of millions. Access to the waters of the South China Sea and Gulf of Thailand in order to exploit these abundant living resources therefore represents an enduring maritime concern of the littoral States. It follows that the preservation and protection of the marine environment supporting living resources that are so crucial from a

108 See UNEP/GEF Reversing Environmental Degradation Trends in the South China Sea and Gulf of Thailand project website at www.unepscs.org. See also Schofield, supra note 40, at 17-18.

109 United Nations Environment Programme (UNEP), Global International Waters Assessment. South China Sea: Regional Assessment 54 (Kalmar, Sweden: University of Kalmar, 2005), 40-1. See also, Rahman and Tsamenyi, supra note 104 , at 319 . 
food security perspective should be top policy priority for the governments concerned. This is especially the case in reference to the vulnerable coral reef ecosystems of the disputed South China Sea islands, which provide important nursery and breeding grounds that are crucial to sustaining the fishery as a whole. In fact, however, the marine environment, biological diversity and living resources in question are under serious threat. ${ }^{110}$ It remains decidedly unclear whether this factor is accorded the priority it deserves in practice, at least partially because of rival claims to sovereignty and also arguably misleading perceptions and priorities attached to hydrocarbon resource exploration and development.

\section{E. The Evolving Military and Strategic Context}

As is well known, all of the claimants to the Spratly Islands save for Brunei have backed up their claims to sovereignty with island occupations. While the terms of the 2002 Declaration on the Conduct of Parties in the South China Sea (DoC) tended to forestall further island occupations, existing facilities have been maintained and in some cases substantially improved. In this context reports in mid-2011 that Chinese vessels had been observed 'unloading construction materials' on a previously unoccupied feature, Amy Douglas reef, raised significant concerns. ${ }^{11}$ Should China or any other claimant go ahead and construct a new facility and occupy a previously unoccupied feature, this would represent a clear breach of the DoC, which calls on parties to 'exercise self-restraint in the conduct of activities that would complicate or escalate disputes and affect peace and stability including, among others, refraining from action of inhabiting on the presently uninhabited islands, reefs, shoals, cays, and other features' ${ }^{112}$ While the military worth of these garrisons, save perhaps as listening posts, is

110 It has been suggested that over $80 \%$ of reefs are at great risk and will collapse within 20 years unless unsustainable practices are abated; $70 \%$ of mangrove cover has been lost in the last 70 years and at current rates of habitat loss the remainder will be lost by $2030 ; 20-60 \%$ of seagrass beds have similarly disappeared over the last 50 years and those still in existence are also threatened with destruction. Ibid.

111 Greg Torode, 'China's Pledges Fail to Convince Security Forum', South China Morning Post, 6 June 2011, online: South China Morning Post http://www. scmp.com/portal/site/SCMP/menuitem.2c913216495213d5df646910cba0a0a0/?vg nextoid=fac1828573060310VgnVCM100000360a0a0aRCRD\&vgnextfmt=teaser $\&$ ss $=$ China\&s $=$ News.

112 See for example, Nguyen Hong Thao, 'The 2002 Declaration on the Conduct of Parties in the South China Sea: A Note', (2003) 34 Ocean Devel \& Int'1 $\mathrm{L}$, at $279-85$. 
questionable, ${ }^{113}$ fresh occupations of features could have a destabilising impact, would be likely to have a negative influence on the fragile environment of the disputed islands and should be set in the overall strategic context of the South China Sea.

An important allied consideration in the overall geopolitics, and geopolitical competition, affecting the South China Sea disputes is the evolving military and strategic balance in the South China Sea. It is abundantly clear that the People's Liberation Army (PLA) of China is undergoing a rapid process of modernisation efforts, backed by the largest defence budget in Asia - second only to the United States globally. While it is the case that other South China Sea claimants are also actively pursuing force modernisation initiatives, the pace and scope of the transformation of the PLA-Navy significantly outstrips their combined efforts. This shift in the regional balance of power and, particularly, the growing asymmetry in military terms between China on the one hand and the other South China Sea claimants on the other, affect the strategic and geopolitical context of the South China Sea disputes. ${ }^{114}$ Arguably, if this trend is maintained, as seems likely, China may have greater scope to uphold what it perceives to be its legitimate territorial and maritime claims, including through increasingly assertive and even coercive means. Indeed, it has been suggested that the South China Sea disputes, and thus the need to effectively protect and reinforce sovereignty and jurisdictional claims, are themselves significant drivers for regional naval modernisation efforts. ${ }^{115}$ Even if this proves not to be the case, the fact remains that all of the South China Sea claimants are engaged in efforts to enhance their militaries, often with territorial and maritime disputes invoked as the justification for arms purchases. These developments, coupled with the failure of the parties to the DoC to implement the conflict management and avoidance mechanisms envisaged within that document, mean that the South China Sea is an increasingly armed environment. This, in turn, raises the stakes and the risks of confrontational incidents. It should also be recalled that the waters of the South China Sea are not solely the preserve or of interest to the

113 Although it has been suggested that facilities in the Spratly Islands could conceivably be used as bases to disrupt shipping, it has also been acknowledged that their small size renders them highly vulnerable to attack and of 'minimal strategic value in any significant conflict'. See Rahman and Tsamenyi, supra note 104 , at 320 .

114 See Clive Schofield and Ian Storey, The South China Sea Dispute: Increasing Stakes, Rising Tensions, Occasional Paper (Washington DC: The Jamestown Foundation, October 2009), at 23-4.

115 Rahman and Tsamenyi, supra note 104, at 319. 
littoral States and Taiwan. A number of extra-regional States, notably the United States, but also India, Japan and Korea, have legitimate concerns in the South China Sea and the interest and presence of these States in the South China Sea appears likely to grow in the future, potentially adding complexity to the geopolitical and operational picture. ${ }^{116}$

\section{CONCLUDING THOUGHTS}

The South China Sea is complex in terms of its coastal geography. The semi-enclosed nature of the South China Sea, coupled with the multiple States bordering it mean that maritime entitlements converge and overlap. Further, the eastern and southern margins of the South China Sea are formed by islands and archipelagoes and the South China Sea itself is host to a profusion of insular features of one type or another, many of which are subject to competing claims to sovereignty. These territorial disputes, coupled with uncertainties over what type of insular feature is under discussion and therefore what capacity a particular Spratly 'Island' may have to generate claims to maritime jurisdiction or influence a maritime boundary delimitation line, considerably complicate the jurisdictional picture in the South China Sea. Add excessive claims to baselines and expansive and historically-inspired unilateral maritime claims and the level of complexity increases considerably, leading to substantial, though not entirely certain, areas of overlapping maritime claims and, indeed, overlaps of overlaps where the same maritime space is subject to the claims of multiple States. That said, it is worth observing that some progress, especially peripherally, has been made. A number of maritime boundary agreements and interim joint arrangements of a practical nature have been reached. There may also be some hints of increased clarity in existing and heretofore worryingly opaque jurisdictional claims. Overall though the geographical and maritime jurisdictional picture in the South China Sea is one of continued and daunting complexity and uncertainty.

With respect to the geopolitical drivers of the South China Sea disputes, sovereignty continues to have a corrosive influence that is extremely difficult to overcome. States are, by their nature, territorial and there is ample evidence of this type of behaviour among the South China Sea littoral States and Taiwan. The South China Sea territorial disputes over islands cannot, however, be divorced from disputes over their associated maritime spaces and the valuable marine resources within these areas.

116 Ibid, at 329; see, also, Schofield and Storey, supra note 114, at 38-41. 


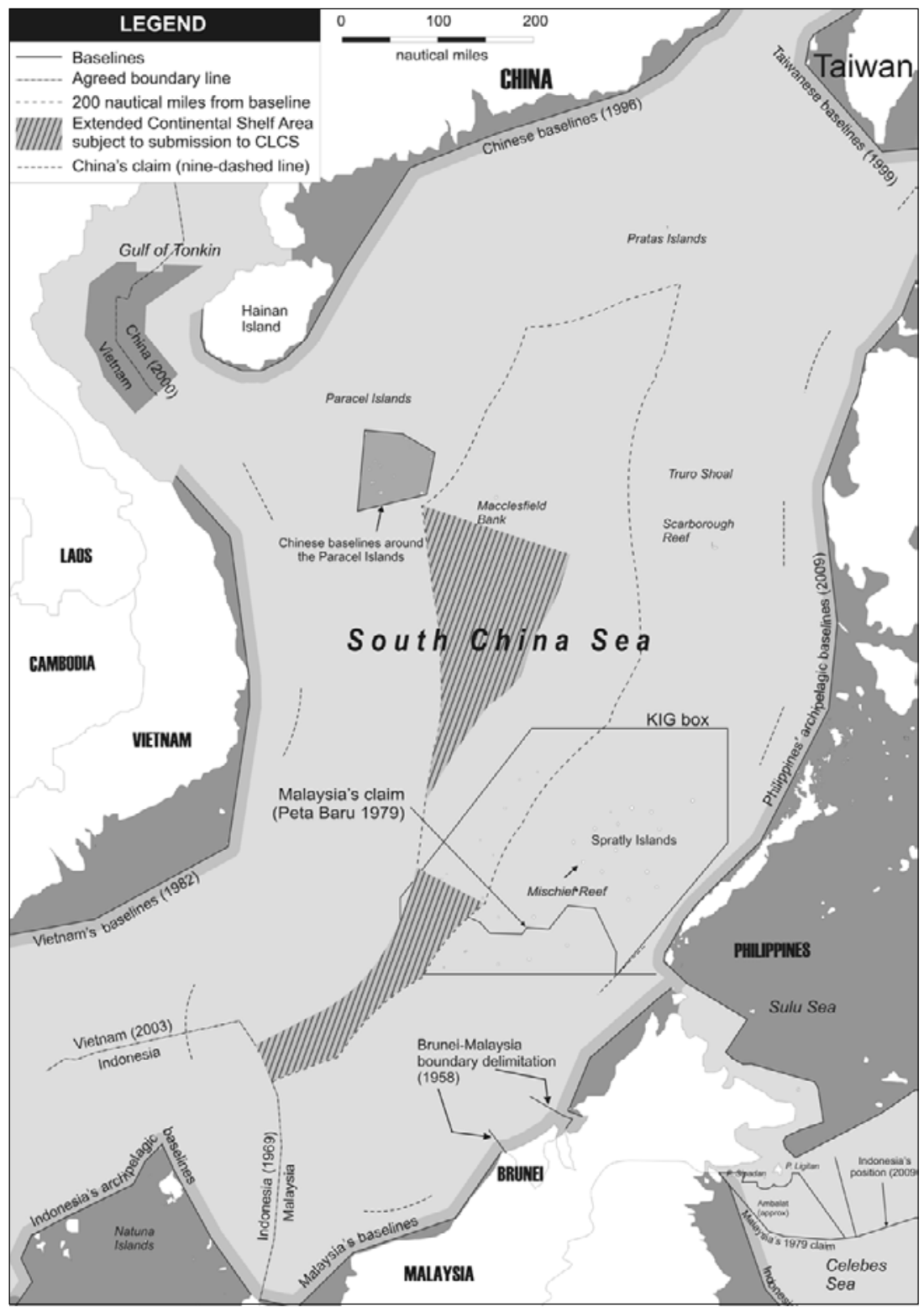

Source: Andi Arsana and Clive Schofield, Australian National Centre for Ocean Resources and Security (ANCORS), University of Wollongong, Australia

Figure 1.1 South China Sea 
Here a reordering of priorities is surely advisable. The waterways of the South China Sea certainly remain critical for all of the parties involved, especially from the point of view of trade and energy flows and this is likely to remain a shared concern. However, while there continues to be a strong perception that the South China Sea is host to substantial seabed energy resources, it is suggested that, even should substantial oil and gas reserves exist, they are unlikely to solve escalating regional energy security concerns. Arguably of more urgent importance is ensuring the protection of the South China Sea's marine environment with a view to ensuring the sustainability of South China Sea's fish stocks upon which millions depend for their primary protein needs. The geopolitical outlook for the South China Sea, in particular based on recent confrontational trends and set against a backdrop of increasing militarization of the area, is one that emphasises competition over co-operation. This, however, only reemphasises the pressing need for efforts to overcome the jurisdictional and geopolitical impasse. Maritime joint development zones and provisional arrangements of a practical nature provide an important and enticing potential opportunity in this regard. 